ment, at Troms $\varnothing$; special attention will be devoted at this well-equipped and favourably situated observatory to this side of auroral research. A further remarkable observational discovery concerning the aurora, due to Størmer, is the recognition that the specially high auroræ, sometimes seen in the west after sunset, or in the east before sunrise, are in the part of the atmosphere, beyond the earth's shadow, still traversed by the sun's rays.

On the side of theory, the advances have been of comparatively recent date. Birkeland laid the foundations, by his speculations and experiments, on which Størmer has reared a great mathematical superstructure, developing the hypothesis that the aurora is due to electrically charged particles from the sun; these are deflected by the earth's maignetic field towards the polar regions, thus explaining the geographical incidence of auroræ. Størmer has deduced from this hypothesis the existence of the two auroral zones, and many other observed features of the aurora. But valuable and successful as the present theory is, it suffers, as Schuster indicated, from a great and deep-lying defect. Of the forces which guide the particles, the theory considers only the electromagnetic, whereas there will also be important electrostatic forces, which the theory ignores; the latter arise from the mutual influence of the particles, which must be partly positive and partly negative, in nearly equal numbers. A new theory must be built up, taking both sets of forces into account; this promises to be exceptionally difficult, and only the merest beginning has yet been made. It is to be hoped that, in the future development of the work, much of the existing theory will find a place, being preserved in a larger structure, as has happened in many other branches of physical theory; but of this it is still too soon to judge.

At the present time we stand, it is hoped, on the eve of a further advance in the observation and theory of the aurora, and of its associated phenomenon, magnetic disturbance. Expeditions are now proceeding to take up their stations at many points in and near the arctic circle, in connexion with the new International Polar Year for scientific research on magnetism, auroræ, and meteorology. With modern instruments and methods, a great extension of the knowledge afforded by the first Polar Year, 1882-83, may confidently be looked for. The British magnetic and meteorological expedition, led by Mr. J. M. Stagg, left for Fort Rae early in May; among other items of its programme is included the determination of auroral heights, from two stations connected by cable or radio. Another British expedition, under Prof. E. V. Appleton, will leave shortly for Tromsø, to determine, by radio methods, the amount, distribution, and changes of ionisation near the auroral zone ; its results should be of extraordinary interest and value for both auroral and magnetic research.

\title{
Obituary
}

Sir Thomas Legge, C.B.E.

$\mathrm{T}^{\mathrm{H}}$ HE death on May 7 of Sir Thomas Morrison Legge, late Senior Medical Inspector of Factories, deserves more than a formal note; for his official record in this capacity was coterminous with the chief reforms in factory hygiene which have occurred. In securing these he played an essential part.

Legge was the son of a distinguished Chinese scholar. After taking his degree with honours at Oxford, he investigated public health conditions in European countries, and described their municipal administration in a volume which may still be referred to with advantage. After serving as secretary of the Royal Commission on Tubereulosis, 1896-98, he worked in public health in Brighton, and afterwards was appointed the first Medical Inspector of Factories and Workshops, a post held by him for nearly thirty years. In this capacity he undertook many important investigations; among others, the relation of cataract to the glare in a glass-blowing factory, the causation of nystagmus, and the origin of various other industrial conditions, in which questions of compensation arose.

Legge gave the Milroy lectures before the Royal College of Physicians on anthrax ; and some years later his distinction in industrial medicine was indicated by his receiving from the same College the Bisset Hawkins medal as a pioneer in public health. He was instrumental in securing the establishment of an official disinfecting station for wool coming from anthrax-infected countries.

Legge's life-work was largely concerned with investigations of industrial lead poisoning and with securing regulations against these risks; and the record of steadily diminishing incidence of cases of lead poisoning year by year is eloquent testimony to the success of his work and that of his colleagues. In 1921 at Geneva thirty countries, including Great Britain, had agreed to a draft Convention, under which it was intended to prohibit the use of lead paint for internal painting. In 1927 Great Britain, however, while regulating the employment of lead paint, did not make its prohibition absolute, and Legge resigned his post at the Home Office in protest, a year or two before his appointment lapsed by flux of time.

Before and after his retirement Legge did valuable work in promoting industrial hygiene, by lecturing on his subject in America and in Great Britain. He held very strongly that for medical students industrial hygiene and poisoning were left almost entirely out of the medical curriculum. He was also insistent that the psychology of the worker should be more fully studied and considered.

Throughout his life, Legge took great interest in the artistic side of the worker's work ; and outside his daily work he delighted in discovering examples of old church and other stained glass. In this subject he was, indeed, an authority, and had at one time a valuable collection. 
Legge's outstanding personal characteristies were modesty and unyielding integrity. He was concerned with his work, not with credit that might come from it; and it is most satisfactory, therefore, that we can now recall with gratitude his extremely important contribution to the welfare of industrial workers in Britain and in other countries.

A. N.

\section{Prof. Otto Fischer}

We regret to record the death on April 4, after a prolonged illness, of Prof. Otto Fischer, who was associated for many years with his more famous cousin, the late Emil Fischer. From the ChemikerZeitung we learn that Otto Fischer was born in 1852 at Euskirchen, near Cologne. On leaving school, he studied for a short time with Kekulé at Bonn before proceeding to Strassiburg, where he began his researches on the synthesis of hydrocarbons under Adolph von Baeyer, and where Emil had already begun his career. After graduating in 1874, Otto proceeded to Charlottenburg to work with Liebermann, but two years later he rejoined von Baeyer, who had in the meantime been called to Munich. In Munich the cousins Fischer worked upon the preparation of organic hydrazines and upon the dyestuffs of the triphenylmethane group. In 1882 , Emil was appointed to the chair at Erlangen, but his health broke down and, in 1884, Otto was sent to act as his substitute. In the following year, Emil accepted the chair at Würzburg, and Otto was appointed to succeed him at Erlangen. This post he held until his retirement in 1925 .

In conjunction with his assistants and students, Otto Fischer published a considerable number of papers on organic chemistry--his favourite field of research being dyestuffs. In conjunction with $D r$. E. Hepp, of the Höchster Farbwerke, he investigated nitrosamines and nitroso-bases, the reactions of the iminazol-group, the safranines, indulines, and fluorindines. Later he worked upon the photosensitising dyestuffs of the cyanin group. He also investigated derivatives of pyridine, quinoline, and anthracene, and he discovered the drug kairine.

WE regret to announce the following deaths:

Prof. Fritz Drevermann, professor of palæontology in the University of Frankfort-on-Main, and editor of the Paläontologischen Zeitschrift, on March 16, aged fifty-seven years.

Dr. Carl Leo Mees, president emeritus of the Rose Polytechnic Institute at Terre Haute, Indiana, who was twice vice-president of Section A of the American Association for the Advancement of Science, on April 20, aged seventy-eight years.

Dr. Roland Thaxter, emeritus professor of crypto. gamic botany at Harvard University, and honorary curator of the Farlow Herbarium, who was a member of the National Academy of Sciences and foreign member of the Linnean Society of London, on April 22, aged 73 years.

\section{News and Views}

\section{Sir Henry Wellcome, F.R.S.}

AT a meeting of the Royal Society on May 26, Sir Henry Wellcome was elected a fellow of the Society under Statute 12, which provides for the recom. mendation by the Council for election of "persons, who ... either have rendered conspicuous service to the cause of science, or are such that their election would be of signal benefit to the Society". Sir Henry, who was knighted last January for his public services, has been a generous and frequent benefactor of scientific research. In 1899 he founded the Wellcome Tropical Research Laboratories in Khartoum, where the late Sir Andrew Balfour worked for many years; he established in England in 1913 his Bureau for Scientific Research and Historical Medical Museum, and in 1914 the Museum of Medical Science, including Tropical Medicine and Hygiene; in 1920 he founded the Wellcome Entomological Field Laboratory. Last year, Lord Moynihan laid the corner-stone of the Wellcome Research Institution, where the Historical Medical Museum and Museum of Medical Science will be brought together under one roof, and facilities provided for research in medical zoology, parasitology, entomology, tropical medicine, and hygiene-the corner-stone, as Lord Moynihan remarked, of a long life's work. Sir Henry Wellcome's election to the Royal Society is a fitting acknowledgment of one who has done as much as anyone in Great Britain to promote the advance of the science and art of medicine.

\section{Scope and Needs of Medical Research}

Srr Watter Morley Fletcher delivered the Friday evening discourse at the Royal Institution on May 27, taking as his subject "The Scope and Needs of Medical Research". He pointed out that medical research covers immensely wide and varied fields of scientific activity, indefinitely wider than the important part of it which concerns the healing profession as such. Its scope has been defined for Parliamentary purposes as dealing with "the proper development and the right use of the human body in all conditions of activity and environment, as well as with its protection from disease and accident, and its repair". The development of the body includes the relatively new and rapidly growing studies of genetics on one hand, and of nutrition on the other. For the right use of the body we are concerned with personal hygiene as well as with the intricate group of problems belonging to industrial life. Here research is organised under the Industrial Health Research Board. Protection from disease covers the two great fields of preventive and of curative medicine. It deals with the genetic and nutritional control of disease, as well as with studies of infective disease at home and in the tropics. This infinitely varied field of work calls at every point for the intensive application of the primary sciences. This is well illustrated by the study of rickets, the detection of its dietetic basis, and the discovery of the relationship of light radiation to the fat-like substance

No. 3266 , Vor. 129] 